\title{
Anticipating the transition to parenthood: the contribution of Foucaultian discourse analysis to understanding life-course patterns
}

\author{
Schwiter, K
}

\begin{abstract}
Existing analyses of life-course transitions tend to take either an institutional or an agency perspective. The aim of this paper is to show how a discourse analytical approach might contribute to bridging the gap between the two perspectives and thereby broaden our understanding of life-course trajectories. To do this, it presents an empirical study that looks at how young Swiss adults anticipate the transition to parenthood. The findings show that young adults are confronted with conflicting and opposing norms concerning parenthood. On the one hand, there is the idea of free choice as to whether and when to have a child. On the other hand, there exist persisting societal prescriptions that govern who may legitimately become a parent. Whoever does not fulfil the required conditions - the discourse suggests - should not have children. The discourse perspective thus brings to the fore what counts as shared knowledge in a particular place and at a particular historical moment. It indicates how the social construction of the transition to parenthood forges particular life-course trajectories.
\end{abstract}

DOI: https://doi.org/10.1111/j.1475-4762.2010.00975.x

Posted at the Zurich Open Repository and Archive, University of Zurich

ZORA URL: https://doi.org/10.5167/uzh-39565

Journal Article

Accepted Version

Originally published at:

Schwiter, K (2011). Anticipating the transition to parenthood: the contribution of Foucaultian discourse analysis to understanding life-course patterns. Area, 43(4):397-404.

DOI: https://doi.org/10.1111/j.1475-4762.2010.00975.x 


\title{
Anticipating the transition to parenthood: the contribution of Foucaultian discourse analysis to understanding life course patterns ${ }^{1}$
}

\author{
Karin Schwiter \\ Department of Geography, University of Zurich, CH-8057 Zurich, Switzerland \\ E-Mail: karin.schwiter@geo.uzh.ch
}

\begin{abstract}
Existing analyses of life course transitions tend to take either an institutional or an agency perspective. The aim of this paper is to show how a discourse analytical approach might contribute to bridging the gap between the two perspectives and thereby broaden our understanding of life course trajectories. To do this, it presents an empirical study which looks at how young Swiss adults anticipate the transition to parenthood. The findings show that young adults are confronted with conflicting and opposing norms concerning parenthood. On the one hand, there is the idea of free choice as to whether and when to have a child. On the other hand, there exist persisting societal prescriptions that govern who may legitimately become a parent. Whoever does not fulfil the required conditions - the discourse suggests - should rather not have children. The discourse perspective thus brings to the fore what counts as shared knowledge in a particular place and at a particular historical moment. It indicates how the social construction of the transition to parenthood forges particular life course trajectories.
\end{abstract}

\section{Introduction}

This paper looks at how young adults anticipate becoming parents. The transition to parenthood has become a vigorously debated issue in scientific as well as public debates. The discussion is fuelled by demographers' diagnoses of low fertility rates and their predictions of rapidly aging and shrinking populations in many European countries (e.g. Frejka and Sobotka 2008, Reher 2007). Why do we find the paradoxical situation of falling birth rates, while surveys show that at the same time

${ }^{1}$ paper accepted for publication in Area's forthcoming special issue on "Theorizing Life Transitions“" 
the wish to have children is unwaning (Beck and Beck-Gernsheim 2001, 119)? Why or why not do people today choose to have children? The paper explores these questions based on interviews with young Swiss adults aged 24 to 26 , who have not (yet) experienced the transition to parenthood.

A substantive body of work on life course transitions already exists. In their review of the state of the art in life course research, Marshall and Müller (2003) distinguish between two main approaches: on the one hand, scholars analyse the impact of social institutions on individual lives. This so-called structural or institutional approach focuses on how life course trajectories are shaped by institutional frameworks. They analyse and compare how different child care, school, work and social security regimes create particular life trajectories and transitions, i.e. a geography of life course patterns (e.g. Krüger 2009, Weymann 2009). On the other hand, scholars examine how individual agency shapes life courses. The so-called agency or biographical approach focuses on individuals as agents and sculptors of their own biographies (e.g. Barabasch 2006, Heinz 2009, Leccardi 2006). Life course research has witnessed longstanding, major debates on the respective relevance of social structure and individual agency on life course trajectories (Heinz and Krüger 2001, 30, Settersten and Gannon 2009, 456ff). Today, most authors agree on the basic stance that institutional regulation and personal behaviour are both equally relevant for understanding life courses. There have been numerous attempts at bringing the two approaches together (most recently see for instance Elder and O'Rand 2009). Still, most studies take their main interest in either institutions or agency. Attempts at bridging the gap are prone to bear the mark of the shore from which the bridge was built. Developing research frameworks which successfully bring together the two strands thus remains one of the major challenges in life course research (Heinz et al. 2009a, 23, Settersten and Gannon 2009, 457).

One of the reasons for the persistence of two separate schools lies in their different methodologies (Weymann 2009, 114). While the agency approach primarily works with qualitative research methods and draws on biographical narratives and ethnographic data to understand how individuals interpret and handle their life experiences, the institutional approach relies to a greater extent on standardised, quantitative data (Heinz and Krüger 2001, 32). In this paper I will suggest a third way 
of looking at life course patterns by adopting a discourse perspective. I argue that discourse theory allows the linking of the two approaches that have so far stood apart. The potential of discourse analysis to provide an additional, complementary means of analysing life course patterns has been recognised by several scholars already. More than a decade ago, Weyman (1996, 244ff) pointed out that discourse theories can grasp the complex interrelations of institutional structures and individual biographies. In his comprehensive introduction to life course and biographical research Sackmann predicts that discourse analysis will play a key role in the future development of the field (2007, 204f). Recent contributions by Spies (2009) and Tuider (2007) discuss how biographical research and discourse analysis could be brought together in empirical studies. Until now, however, discourse analytical research on life course issues remains rare and has so far gone largely unrecognised in the field of life course research.

The intention of this paper is to show how a discourse analytical approach can contribute to understanding life course patterns. To do this, I study anticipated transitions to parenthood. Taking a discourse analytical approach, I ask how the prospect of becoming a parent is anticipated by young Swiss adults. How do they talk about the transition to parenthood in their life plans? What norms do they refer to? How do they thereby (re)produce what we call "the transition to parenthood" in a particular way?

\section{State of the art}

My approach builds on the work of Katz and Monk (1993), Teather (1999) and others who drew attention to the amplitude of historical and cross-national variability of life courses and transitions in the 1990s. Their seminal collections revealed the importance of time and place in the construction of life paths. Life courses have both a history and a geography. As Hopkins and Pain $(2007,290)$ point out, seeing life course stages and the transitions between them as socially constructed allows the analysis of their geographically and historically situated meanings.

I also build on existing research looking at the transition to parenthood, which is often conceptualised as one step in the transition from youth to adulthood. Comparing different geographical settings, several studies come to the conclusion that the 
transition to adulthood has become increasingly de-standardised, inconsistent and problematic in the recent past (e.g. Aassve et al. 2007, Den Dulk et al. 2003, Jeffrey and McDowell 2004, Leccardi 2006, Liefbroer 2009, McIlwaine and Datta 2004, Mills et al. 2005, Valentine 2003). These authors argue that there is no predefined, clear-cut series of steps that lead to the status of an adult.

A number of authors have suggested different concepts to capture the fluidity, complexity and uncertainty that characterise current transitions to adulthood. Arnett (2006) coined the term "emerging adulthood" to capture the in-between status that young people experience at the threshold to adulthood. Bradley and Devadason (2008) speak of "fractured transitions" and Biggart and Walther (2006) call them "yoyo-transitions". In sum, a review of the existing literature shows broad agreement on the perspective that increasing uncertainties accompany the transition to adulthood (which does not imply that adult lives are essentially more stable). As a consequence, there is a lengthening of the youth phase that may last well into an individual's thirties.

However, some scholars point out that the changes claimed to have taken place in the past decades are often exaggerated (Furlong 2006) and many of them are only true for affluent Western societies (Helve and Holm 2005). Furthermore, Bynner (2005) and Widmer and Ritschard (2009) draw attention to the danger inherent in generalising too broadly. Bynner suggests conceptualising the transition to parenthood as "differenciated pathways" in order not to hide the persistent influence of structuring factors such as class, gender, ethnicity and locality. Additionally, Westberg (2004) shows that a marked difference exists between the view of attaining adulthood conceptualised in scientific studies and young people's own views of this transition.

Becoming a parent is understood to be a transition in one's life course, which is part of and embedded in the process of becoming an adult (Sobotka 2004). Hagestad and Call (2007) for instance found evidence that protracted transitions in early adulthood, i.e. leaving the parental home or gaining economic independence, had domino effects on the timing and achievement of later transitions such as becoming a parent. In accordance to the discussion sketched above, studies that look at first parenthood in 
particular present evidence for a growing de-standardisation, protraction and complexity of this transition.

In addition to these trends applying to the transition to adulthood in general, researchers stress that having a child must be understood as the joint decision of two persons and as an aspect of gender relations (e.g. Huinink 2009). The important claim that analyses must consider the linkages between the life courses of couples and other family members has long been disregarded in life course studies. It was first introduced in the 1990s by Elder (1994, cited in Huinink 2009, 304). His notion of "linked lives" was then taken up especially in studies focussing on gender (e.g. Born and Krüger 2001). Becoming a parent constitutes the one life course transition in which the interwovenness of life courses comes to the fore most prominently. Discussing the example of single mothers, Hertz (2006) demonstrates how the transition to parenthood is intrinsically bound up with the idea of a (heterosexual) couple taking the step together. In recent years the concept of linked lives has received increasing attention in the field (e.g. Aassve et al. 2007, Heinz et al. 2009b, Heinz and Marshall 2003, Levy et al. 2006, Macmillan and Copher 2005). Bailey et al. (2004) for example demonstrate how life course decisions are not only linked to spouses and partners, but are also highly dependent on intergenerational ties between children, parents and grandparents. Nevertheless, there are still numerous studies that fall short of considering the interlinking of life courses in their research frameworks (Huinink 2009, 308f).

This paper takes up these issues currently being discussed in research on life transitions and asks how they are reflected in the transition to parenthood as it is (re)produced in the narratives of young adults. Unlike biographical studies, I do not focus on the variability of meanings that individuals attribute to parenthood and their decision making strategies, but employ a Foucaultian discourse perspective to shed light on how the transition is socially constructed in norms and conventions.

The key idea of this approach is to look at how meaning and knowledge are produced through language. Foucault (1972) argues that the way we speak and write about something produces this object of study in a specific way. In order to analyse this discursive construction of meaning, he collects statements that deal with the object of 
study and analyses the patterns that characterise them. He then tries to describe the rules that prescribe the specific way of talking about the topic in question. These norms and conventions establish what is counted as "normal", "natural" or "selfevident", and what is considered "deviant" or "problematic". They are socially constructed and continually (re)negotiated as people discuss, contest or reaffirm them. They govern what is "sayable" and "thinkable" about the topic in a particular place at a particular historical moment (Hall 2001, 72f). In my analysis of interview transcripts, I thus did not look at individual biographies, but at the patterns which characterised the way in which young adults spoke about, and thereby constructed, the transition to parenthood.

\section{Methodology}

The empirical study is based on 24 narrative interviews with young adults aged between 24 and 26. They have not yet had children and were living in the Germanspeaking part of Switzerland. The choice of interviewees was guided by theoretical sampling, as suggested by Glaser and Strauss (1967). This means that data collection and data analysis were set up as parallel, iterative processes. I started assembling the sample by using a set of predetermined criteria that defined the specific group of young people I wanted to focus on. These included childlessness, age and locality as described above. Within this contextual frame I aimed for the highest possible variability with regard to educational and occupational backgrounds. Considering the preliminary findings from the analysis of the first interviews, I specifically chose interviewees who had the potential of bringing in additional perspectives that had not been captured so far. To do this, I included for instance homosexual people, young adults from single parent families, with a migratory background, with an interest in religion, etc. The participants were recruited by means of private networks, via gatekeepers and calls for participation on mailing lists.

The narrative interviews lasted from one and a half to three hours. I started by asking: "Would you like to tell me the story of how you grew up?" Setting off from the past, the interview then moved on to the present. Its primary focus lay on the young adults' plans for their future. The anticipation of a possible transition to parenthood was part of this main area of interest. The interviews were recorded and transcribed. I then analysed the transcripts using Foucaultian discourse analysis. 


\section{Results}

The analysis of the narratives shows that the transition to parenthood is constituted by two conflicting discourses. On the one hand, there is a discourse that conceptualises parenthood as free choice. It understands young adults as autonomous designers of their individual life paths. According to this discourse, the question of whether and when to have children is seen as entirely up to the individual. On the other hand, the narratives of the young adults comprise a second discourse suggesting that only those who fulfil a prescribed set of requirements are entitled to have a child. In the following section I will try to illustrate in detail how these two discourses work.

First and foremost, the interviews show a discourse of individualisation. The young Swiss adults interviewed for this study perceive themselves very much as individuals. They consider it normal that every person likes to do things his or her own way, regardless of what other people do. Concerning parenthood, the interviewees typically say, for instance:

\footnotetext{
"For me, a fulfilling life means having children."

"I personally, don't feel the need to have a child."

"I've always wanted to be a young mother."

"I'm not the type of person who makes family plans."
}

These very short extracts from the interview transcripts illustrate that young adults view themselves as individual beings with specific traits and needs that distinguish them from others. The key idea they convey is that people make choices based on their individuality. The interviewees state, for example:

"I listen to my inner voice to find out what's good for me."

"Every person is different. You cannot impose your own preferences on others." 
"It all comes down to individual choices. Everyone has got to decide for himself, what's best for him."

This discourse of individualisation also applies to life transitions. Mirroring Beck's theory of individualization (Beck and Beck-Gernsheim 2001), life paths are seen by these interviewees not as predefined by society, but as individually chosen. According to the interviewees, an individual faces a multiplicity of options from which everyone is free to choose based on one's individual preferences.

As for the transition to parenthood, the discourse suggests that it is up to the individual to decide whether and at which moment in life one should become a parent. One interviewee expresses this explicitly by saying: "In the end, each and everyone has to decide on their own, whether or not to have a child." This discourse of individualization and free choice comes across very powerfully in the interviews. It conveys that any person can have a child as and when they decide that it is the right thing to do for them at that specific stage in life.

However, at the same time, the interviews display a second discourse that contradicts the notion of free choice to a certain extent. While discussing their possible transitions to parenthood, the young adults stated a whole set of prerequisites that have to be met before someone may rightfully think of having a child. First of all, a person who plans to have a child must have completed their education. Secondly, one must have settled into a job. Furthermore, one must have enough savings to be able to support a child financially. And most importantly, one needs to find a partner for life. Additionally, both partners have to agree on the division of labour in the future family. Finally, both of them need to "feel ready" to carry the responsibility of having a child:

"One has got to finish school before having a child. That is clear as daylight."

"If you do not agree with your husband on who should look after the kids, you should rather not have any. That goes without saying"

"A child costs a lot of money. One has got to be able to provide for it." 
"Before thinking about having a child you have got to find someone with whom you want to spend the rest of your life"

"If you are not ready to always put your children first, do not have any."

The young adults phrase these prerequisites as general rules applying to all adults on the threshold to parenthood. If a single one of these is not fulfilled, the interviewees conclude that one should rather not have children.

The discourse is further supported by a variety of "horror stories". The interviews provide a number of accounts of couples who became parents although they neglected the stated prerequisites, as a result of which child and parent suffer. The moral of the stories is then typically that they had better not had children in the first place. One short account, for example, goes as follows:

„I cannot understand young women who get pregnant in the first flush of falling in love. Having a child requires a lot more. I've got several friends who became pregnant after just four months of being together. I repeat it again and again: that's no good! (...) In the end, they all get what was to be expected. Their families fall apart and the women are left behind as single mothers with no money at all."

Stories such as the above not only suggest that the transition to parenthood is governed by a set of preconditions that must be met, but also that responsibility for the 'choice' to have children rests first and foremost with the female partner in a relationship.

The narratives of other interviewees also reveal differing norms depending on gender. For men, having settled into a job means being in secure, long-term and full-time employment with good earning opportunities. For women, it means being in an employment situation that allows quitting for at least a few months and then returning on a part-time basis. Similarly, "feeling ready" for children for men entails taking over the main responsibility of earning the family income. For women it means taking 
over the responsibility of being the prime caregiver of the children. Thus, some of the preconditions are based on gendered expectations of what the transition to parenthood entails for men and for women respectively. They refer to a division of labour according to the "male earner-female carer" model (for a more detailed discussion on gendered constructions of parenthood see for instance Den Dulk et al. 2003, Nentwich 2008, Schwiter 2009).

To sum up, in the discourses of young Swiss adults, having a child is conceptualized as an individual, autonomous decision, a matter of free choice on the one hand, and as dependent on a whole set of conditions and gender norms on the other hand.

While these appear to be contradictory, the two discourses do intersect, however, in young people's anticipated life course transitions. One interviewee says for instance: "The big question for me is money. Before I can think of having children, I need more savings." Here, the interviewee refers to the prerequisite of material security, but by introducing it as 'the big question for her', she frames it as an individual preference. As she cannot fulfil the norm regarding finances, she consequently postpones the transition to parenthood. She thereby regards it as her entirely free choice, based on her individual preferences only. As shown in this example, the two discourses typically appear entangled and interwoven. The tension they create contributes to young adults' feelings of ambivalence towards and the postponement of the transition to parenthood. Thus, they strongly affect concrete life course trajectories.

\section{Discussion}

Analysing the accounts of childless Swiss adults aged 24 to 26 this paper offers a discursive perspective on how the transition to parenthood is socially constructed by a specific group of young people. It would be highly interesting to explore to what extent the documented discourses deviate from the narratives of younger or older age groups, of earlier generations of young adults, or of young adults from different cultural contexts (see e.g. Jeffrey and McDowell 2004). It does not lie within the scope of this study to do this. However, though they encompass only a specific group of people, the empirical findings can demonstrate how the perspective of discourse analysis sheds an additional light on life transitions. It links the existing foci on institutional structures and biographical agency by analysing the societal norms and conventions that govern life trajectories in a specific geographical and historical 
setting. Adopting this perspective contributes to current debates in life course studies in several respects:

Firstly, it broadens our understanding of the de-standardisation of life courses, illustrating that 'individualisation' itself has become a normative discursive construction. People are tasked with taking responsibility for their own life paths and transitions that might formerly have been taken for granted are now framed as individual choices (see also Hörschelmann 2008). According to the discourse shown above it is entirely up to the individual to follow his or her particular life path.

The debate in life course studies so far has mainly focused on the problematic aspects of the weakening of standardised trajectories to adulthood. Studies have drawn attention to the growing difficulties young adults experience in trying to reach the status of adulthood, pointing to yo-yo-effects and protractions (see section "State of the art"). In contrast, the discourse perspective shows that - in the narratives of the interviewees - the norm of individualised biographical planning bears an utterly positive connotation. The young adults interviewed for this study understand it as a necessary consequence of the differences between people. If a person does not master a specific transition, this is not seen as problematic but attributed to not choosing to do so, i.e. to differing individual preferences. The discourse perspective thus reveals a positively connoted ideology of freedom of choice, i.e. a strong approval of the notion that every individual is supposed to forge his/her own destiny. Similar findings resulted from analyses of young adults' narratives by Leccardi (2006) in the case of Italy and Barabasch (2006) regarding the USA. It remains to be shown by future research to what extent this conceptualisation of life courses can also be found in the narratives of other age groups and in other cultural contexts. Discourse analysis also shows, however, that the emphasis on individualised preferences and a multitude of life course options conceals the societal norms and structures, by which choices are shaped. The discourse can be read as an incorporated ideology, which delegates all responsibility to the individual, while institutional and systemic obstacles and contradictions in life courses continue to restrict biographical decisions (for a critical discussion of individualisation theory see e.g. Duncan and Smith 2006). 
Secondly, the discourse perspective adds to our understanding of historically and geographically specific life course patterns, e.g. of the reasons for low fertility levels. It sheds light on the fact that young Swiss adults are confronted with conflicting and opposing norms concerning parenthood. There is the idea of free choice as to whether and when to have a child while simultaneously, there are persisting societal prescriptions that govern who may legitimately become a parent. The later discourse has often remained unnoticed in biographical approaches with their focus on individual agency. They document how individuals "choose" their life paths and how they make sense of their experiences. They regard individuals as sculptors of their own biographies and analyse their specific preferences and life course decisions. The discourse perspective offers an additional perspective by identifying the societal norms and conventions that govern these "choices". The analysis presented here was able to reveal a norm suggesting that a person is rightfully entitled to have a child only if s/he meets certain criteria. These include completed education, secure employment, ample savings, a partner for life, agreement on the division of labour and the feeling of "being ready" for the responsibility of a child. As they must all be met at the same time, a considerable proportion of young people - the discourse suggests - should not have children.

Additionally, the conditions must be fulfilled not only by one person but by the couple. Both have to reach a point in their educational and occupational trajectories that allow them to have a child. Both of them have to be convinced that they have a partner for life, that they are "ready" for a child and agree on how their future family will be organised (see also Bergnéhr 2007, 15 and Sassler et al. 2009). The discourse thus offers strong support for the concept of "linked lives" (Elder 1994). It emphasises that life transitions and the transition to parenthood in particular can only be understood as the intertwined trajectories of two persons. This interlinking makes it even more difficult to fulfil the societal prerequisites linked to parenthood.

\section{Conclusion}

Young adults are confronted with conflicting and opposing norms concerning parenthood. There is a tension between the idea of free choice as to whether and when to have a child and the persisting societal prescriptions that govern who may legitimately become a parent. A discourse perspective allows us to make these 
contradictions visible and gives us the opportunity to widen the discussion on low fertility. Instead of asking why many people no longer choose to have children, we might discuss why they cannot meet the requirements Swiss society expects of those who want to cross the threshold into parenthood. Furthermore, it allows us to question the prerequisites themselves. Should only those become parents who are in secure, long-term employment? How does this go together with increasing numbers of people unemployed or working under precarious conditions? Should only those become parents who are sure to have found a partner for life? Does this make sense in view of high divorce rates and the norm of fulfilling one's life course as an individual? How about single people who wish to have a child? What about homosexual couples? In sum, does it make sense that in Switzerland only an exclusive group of people is perceived as legitimized to make the transition to parenthood?

With this paper I have begun to show to what extent a discourse perspective might contribute to bridging the gap between the institutional and the agency-centred approach in life course studies by shedding light on what counts as shared knowledge in a particular place at a particular historical moment. To institutions and agency, it adds norms and conventions, which link micro-, meso- and macro-levels of analysis. I have illustrated this through the example of the norms that define who is allowed to have children and who is not. On the one hand, the normative prerequisites for having a child influence fertility levels as well as arrangements of child benefit and social security regimes, which are analysed by the institution-centred approach. On the other hand, societal norms concerning parenthood influence young adults in their decisions to have children and thus affect their individual biographical trajectories, which are analysed by the agency-centred approach. Discourse analysis not only sheds light on but also, as Rydin (2005) convincingly showed in an earlier issue of this journal, puts norms up for public discussion. It thereby challenges existing frameworks of thought that might otherwise have remained largely unnoticed. It is for this reason in particular that it ought to become more central to life course research.

\section{Acknowledgements}

I would like to thank Kathrin Hörschelmann, who initiated the fruitful discussion on life transitions. Furthermore, I am grateful to Anne Zimmermann, Nicola Feyen, Christian Berndt and the two anonymous reviewers for their comments on earlier 
versions of this paper and to Andrea Maihofer, Nina Wehner, Diana Baumgarten and the other members of the $\mathrm{PhD}$ school in Gender Studies at the University of Basel as well as the Economic Geography Group at the University of Zurich for their support and constructive criticism throughout this project. I would like to extend my thanks to the interviewees who agreed to participate in this project and share their life stories with me.

\section{References}

Aassve A Billari F C and Piccarreta R 2007 Strings of adulthood: A sequence analysis of young British women's work-family trajectories European Journal of Population 23 $369-88$

Arnett J J 2006 Emerging adulthood in Europe: A response to Bynner Journal of Youth Studies 9(1) 111-23

Bailey A J Blake M K and Cooke T J 2004 Migration, care and linked lives Environment and Planning A 36 1617-32

Barabasch A 2006 No worries about the future: Young adults' perceptions of risk and opportunity while attending technical college Journal of Industrial Teacher Education 43(2) 20-44

Beck U and Beck-Gernsheim E 2001 Declining birthrates and the wish to have children in Beck $\mathbf{U}$ and Beck-Gernsheim $\mathbf{E}$ eds Individualization: Institutionalized individualism and its social and political consequences Sage, London 119-28

Bergnéhr D 2007 Love and family: Discussions between Swedish men and women concerning the transition to parenthood. Forum Qualitative Social Research 8(1)

Biggart A and Walther A 2006 Coping with yo-yo-transitions: Young adults' struggle for support, between family and state in comparative perspective in Leccardi $\mathbf{C}$ and Ruspini E eds A new youth? Young people, generations and family life Ashgate, Aldershot 41-62

Born C and Krüger H 2001 Das Lebenslaufregime der Verflechtung: Orte, Ebenen und Thematisierungen in Born $\mathbf{C}$ and Krüger $\mathbf{H}$ eds Individualisierung und Verflechtung: Geschlecht und Generation im deutschen Lebenslaufregime. Juventa, Weinheim und München 11-26

Bradley H and Devadason R 2008 Fractured transitions: Young adults' pathways into contemporary labour markets Sociology 42(1) 119-36

Bynner J 2005 Rethinking the youth phase of the life-course: The case for emerging adulthood? Journal of Youth Studies 8(4) 367-84

Den Dulk L Peper B and Van Doorne-Huiskes A 2003 Transitions: Literature review for the EU framework 5 study, ,gender, parenthood and the changing European workplace" Research Institute for Health and Social Change, Manchester

Duncan S and Smith D 2006 Individualisation versus the geography of 'new' families 21st Century Society 1(2) 167-89

Elder G H 1994 Time, human agency, and social change: Perspectives on the life course Social Psychology Quarterly 57 4-15

Elder G H and O'Rand A M 2009 Adult lives in a changing society in Heinz W R Weymann $\mathbf{A}$ and Huinink $\mathbf{J}$ eds The life course reader: Individuals and societies across time Campus, Frankfurt am Main 430-55

Foucault M 1972 Archeology of knowledge Tavistock, London

Frejka T and Sobotka T 2008 Fertility in Europe: Diverse, delayed and below replacement Demographic Research 19 (3) 15-45 
Furlong A 2006 Balancing change and continuity in Leccardi $\mathbf{C}$ and Ruspini E eds $A$ new youth? Young people, generations and family life Ashgate, Aldershot xv-xvii

Glaser B and Strauss A 1967 The discovery of grounded theory: Strategies for qualitative research Aldine, Chicago

Hagestad G O and Call V R A 2007 Pathways to childlessness: A life course perspective Journal of Family Issues 28(10) 1338-61

Hall S 2001 Foucault: Power, knowledge and discourse in Wetherell M Taylor S and Yates S J eds Discourse theory and practice: A reader Sage, London 72-81

Heinz W R 2009 Transitions: Biography and agency in Heinz W R Weymann A and Huinink $\mathbf{J}$ eds The life course reader: Individuals and societies across time Campus, Frankfurt am Main 421-29

Heinz W R Huinink J Swader C S and Weymann A 2009a Fundamental conceptual frameworks in Heinz W $\mathbf{R}$ Weymann $\mathbf{A}$ and Huinink $\mathbf{J}$ eds The life course reader: Individuals and societies across time Campus, Frankfurt am Main 15-30

Heinz W R and Krüger H 2001 Life course: Innovations and challenges for social research Current Sociology 49(2) 29-45

Heinz W R and Marshall V W eds 2003 Social dynamics of the life course: Transitions, institutions, and interrelations Hawthorne, Aldine

Heinz W R Weymann A and Huinink J eds 2009b The life course reader: Individuals and societies across time Frankfurt am Main, Campus

Helve H and Holm G eds 2005 Contemporary youth research: Local expressions and global connections Aldershot, Ashgate

Hertz R 2006 Single by chance, mothers by choice: How women are choosing parenthood without marriage and creating the new American family Oxford University Press, New York and Oxford

Hopkins P and Pain R 2007 Geographies of age: Thinking relationally Area 39(3) 287-94

Hörschelmann K 2008 Transitions to work and the making of neo-liberal selves - growing up in (former) East Germany in Smith A Stenning A and Willis K eds Social Justice and Neoliberalism: Global Perspectives Zed Books, London

Huinink J 2009 Linked lives, families, and intergenerational relations in Heinz W R Weymann $\mathbf{A}$ and Huinink $\mathbf{J}$ eds The life course reader: Individuals and societies across time Campus, Frankfurt am Main 303-10

Jeffrey C and McDowell L 2004 Youth in a comparative perspective: Global change, local lives Youth and Society 36 131-42

Katz C and Monk J 1993 Full circles: Geographies of women over the life course Routledge, London and New York

Krüger H 2009 The life-course regime: Ambiguities between interrelatedness and individualization in Heinz W R Weymann $\mathbf{A}$ and Huinink $\mathbf{J}$ eds The life course reader: Individuals and societies across time Campus, Frankfurt am Main 159-77

Leccardi C 2006 Redefining the future: Youthful biographical constructions in the 21st century New Directions for Child and Adolescent Development 113 37-48

Levy R Gauthier J-A and Widmer E 2006 Entre contraintes institutionnelle et domestique: Les parcours de vie masculins et féminins en Suisse The Canadian Journal of Sociology 31(4)

Liefbroer A C 2009 From youth to adulthood: Understanding changing patterns of family formation from a life course perspective in Heinz W R Weymann A and Huinink $\mathbf{J}$ eds The life course reader: Individuals and societies across time Campus, Frankfurt am Main

Marshall V W and Müller M M 2003 Theoretical roots of the life course perspective in Heinz W R and Marshall V W eds Social dynamics of the life course. Transitions, institutions, and interrelations. Aldine, Hawthorne 3-32

McIlwaine C and Datta K 2004 Endangered youth? Youth gender and sexualities in urban Botswana Gender, Place and Culture 11 483-511

Mills M Blossfeld H-P and Klijzing E 2005 Becoming an adult in uncertain times: A 14country comparison of the losers of globalization. in Blossfeld H-P Klijzing E Mills 
M and Kurz K eds Globalization, uncertainty and youth in society Routledge, New York 423-41

Nentwich J C 2008 New fathers and mothers as gender troublemakers? Exploring discursive constructions of heterosexual parenthood and their subversive potential Feminism and Psychology 18(2) 207-30

Reher D S 2007 Towards long-term population decline: A discussion of relevant issues European Journal of Population 23 189-207

Rydin Y 2005 Geographical knowledge and policy: The positive contribution of discourse studies Area 37(1) 73-78

Sackmann R 2007 Lebenslaufanalyse und Biografieforschung: Eine Einführung VS Verlag für Sozialwissenschaften, Wiesbaden

Sassler S Miller A and Favinger S M 2009 Planned parenthood? Fertility intentions and experiences among cohabiting couples Journal of Family Issues 30(2) 206-32

Schwiter K 2009 ,ich würde gerne den Hausmann spielen...“ gute und schlechte Väter in den Erzählungen junger Erwachsener in Villa P-I and Thiessen B eds Mütter - Väter: Diskurse, Medien, Praxen Westfälisches Dampfboot, Münster 213-25

Settersten R A and Gannon L 2009 Structure, agency, and the space between: On the challenges and contraditions of a blended view of the life course in Heinz W $\mathbf{R}$ Weymann $\mathbf{A}$ and Huinink $\mathbf{J}$ eds The life course reader: Individuals and societies across time Campus, Frankfurt am Main 456-72

Sobotka T 2004 Postponement of childbearing and low fertility in Europe Dutch University Press, Amsterdam

Spies T 2009 Discourse, subject, and agency: Linking discourse analysis and biographical research with the help of the concept of articulation Forum Qualitative Social Research 10(2)

Teather E K ed 1999 Embodied geographies: Spaces, bodies and rites of passage London, Routledge

Tuider E 2007 Discourse analysis and biographical research: About the how and why of subject positions Forum Qualitative Social Research 8(2)

Valentine G 2003 Boundary crossings: Transitions from childhood to adulthood Children's Geographies $137-52$

Westberg A 2004 Forever young? Young people's conception of adulthood. The Swedish case Journal of Youth Studies 7(1) 35-53

Weymann A 1996 Interrelating society and biography. Discourse, markets and the welfare state's life course policy in Weymann A and Heinz W R eds Society and biography: Interrelationships between social structure, institutions and the life course Deutscher Studien Verlag, Weinheim 241-58

Weymann A 2009 Life course policy: The state and its institutions in Heinz W R Weymann $\mathbf{A}$ and Huinink $\mathbf{J}$ eds The life course reader: Individuals and societies across time Campus, Frankfurt am Main 113-20

Widmer E and Ritschard G 2009 The de-standardization of the life course: are men and women equal? Advances in Life Course Research 14(1-2) 29-39 